\title{
REVIEW : POTENSI DAN ARAH PENGEMBANGAN AGROINDUSTRI BERBASIS KAKAO DI PROVINSI PAPUA BARAT
}

\author{
Murtiningrum $^{1)}$, Tajuddin Bantacut ${ }^{2)}$ \\ ${ }^{1)}$ Jurusan Teknologi Pertanian, Fakultas Teknologi Pertanian Universitas Papua Jl. Gunung Salju Amban. \\ Manokwari-98314, Papua Barat. Email: ningrum_mrt@yahoo.com \\ ${ }^{2)}$ Departemen Teknologi Industri Pertanian, Fakultas Teknologi Pertanian, Institut Pertanian Bogor.
}

\begin{abstract}
West Papua Province as the coverage area of the National Cocoa Revitalization Movement (GERNAS Pro-Cocoa). This area has the potential to become a center for the cocoa production, and even become the main cocoa producing areas in eastern Indonesia. Cocoa plantation area in West Papua province was recorded as 5.509 ha with 3.104 tons of total production. This article aims to provide an overview of cocoa as a national strategic competitive commodities and conditions of cocoa plantations in West Papua province. At the end of the text presented on the direction of cocoa develop agroindustry through institutional capacity building among farmers, groups of farmers, Farmers Group Association (gapoktan), traders, relevant institutions and universities. This paper also presented the opportunities and challenges of developing downstream cocoa industry in West Papua province. Cocoa agroindustry development in West Papua Province needs of reform to the institutional capacity building cocoa between farmers, groups of farmers, gapoktan, traders, wholesalers, relevant institutions and universities. This cooperation can create a new business strength, increasing market coverage, and quality assurance of products. Income of the cocoa farmer can be increased by developing a simple process cocoa processing using appropriate technology. The farmers can produce cocoa downstream products which have a higher economic value.
\end{abstract}

Keywords: cocoa agroindustry, West Papua Province, institutional capacity building, cocoa processing

\section{PENDAHULUAN}

Indonesia termasuk negara pengekspor penting dalam perdagangan biji kakao. Ekspor kakao Indonesia terus mengalami peningkatan dari tahun ke tahun dan memberikan sumbangan devisa ketiga terbesar setelah kelapa sawit dan karet. Sejauh ini kakao mampu menyumbang devisa bagi perekonomian nasional sebesar US\$ 97.291.557 atau 13,18\% dari total ekspor hasil perkebunan nasional dari lima komoditas hasil perkebunan (Kelapa, Karet, Kelapa Sawit, Kopi dan Kakao) (Direktorat Jenderal Perkebunan 2015).

Upaya pemerintah untuk meningkatkan produksi kakao nasional dilakukan dengan program revitalisasi kakao melalui Gerakan Revitalisasi Kakao Nasional (GERNAS Pro-Kakao) yang sudah berlangsung sejak tahun 2009. Program tersebut secara nyata meningkatkan kinerja

dan produktivitas tanaman kakao melalui tiga kegiatan utama yaitu peremajaan, rehabilitasi dan itensifikasi. Dalam program ini juga dilakukan pembinaan pada kelembagaan petani dan pemberdayaan petani itu sendiri. Selain itu, dampak dari program GERNAS Pro-Kakao antara lain munculnya daerahdaerah sentra produksi kakao baru mencakup lima provinsi di Indonesia Timur, yaitu Nusa Tenggara Timur, Bali, Maluku, Papua dan Papua Barat (Neilson 2008).

Masuknya Provinsi Papua Barat sebagai wilayah cakupan GERNAS ProKakao, menjadikan daerah ini berpotensi menjadi sentra produksi kakao baru bahkan sebagai daerah penghasil utama kakao di wilayah timur Indonesia. Luas areal tanaman kakao di Provinsi Papua Barat tercatat 5.509 Ha dengan produksi 3.104 ton (Disbun Papua Barat 2015). Potensi pengembangan 
perkebunan kakao di Provinsi Papua Barat sangat besar jika dilihat dari berlimpahnya bahan baku yang tersedia. Peluang untuk memperoleh nilai tambah dan penyerapan tenaga kerja yang sangat besar harus dimanfaatkan oleh pelaku bisnis kakao di Indonesia.

Namun demikian, potensi pengembangannya masih menghadapi beberapa kendala yaitu belum adanya kerjasama atau ikatan usaha yang terbangun secara memadai antar lembaga maupun kelompok usaha yang terlibat sehingga berimplikasi pada tidak tercapainya tujuan pengembangan agroindustri kakao karena pelaku usaha belum mendapatkan manfaat yang proporsional dengan pembentukan usaha tersebut. Pengembangan agroindustri kakao harus bersifat komprehensip karena memandang pengusahaan kakao sebagai suatu sistem yang kompleks dan bersifat strategis sehingga seluruh komponen pelaku dan kepentingannya masing-masing harus diakomodasi.

Permasalahan lainnya yaitu potensi luas`areal perkebunan kakao belum diikuti peningkatan mutu biji kakao kering dan masih belum berkembangnya industri hilir sehingga terjadi kesenjangan nilai tambah antara hulu dan hilir. Biji kakao basah dijual petani dengan harga berkisar antara Rp10.000-Rp 15.000, sedangkan biji kakao kering dijual dengan harga berkisar antara $\mathrm{Rp}$ 20.000-Rp 35.000 bergantung pada mutu biji kering. Produk kakao Papua Barat sampai saat ini keseluruhannya masih dijual atau dikirim ke wilayah lain di Indonesia (Surabaya dan Makasar) dalam bentuk biji kakao kering tidak fermentasi. Hal ini mengakibatkan nilai tambah dari rantai kegiatan pengolahan komoditas kakao hanya dinikmati sekelompok kecil pelaku usaha kakao terutama pedagang pengumpul yang ada di Kabupaten Manokwari.

Pengembangan agroindustri kakao di Provinsi Papua Barat seharusnya merupakan satu kesatuan sistem dari hulu sampai hilir. Dengan cara ini dapat mengubah pola kemitraan yang telah berjalan namun mengarah pada bentuk kelembagaan informal yaitu pedagang memiliki posisi tawar yang lebih kuat dibandingkan petani. Oleh karena itu, diperlukan suatu kerjasama usaha yang lebih sinergis dan sepadan dalam hal perencanaan, pengembangan usaha, produksi dan pemasaran produk dengan kualitas baik konsisten dalam mengikuti perkembangan konsumen atau selera pasar.

Tulisan ini bertujuan memberikan gambaran tentang kakao sebagai komoditas unggulan strategis nasional dan kondisi perkebunan kakao di Provinsi Papua Barat. Pada akhir tulisan dipaparkan mengenai arah pengembangan agroindustri kakao melalui penguatan kelembagaan antara petani, kelompok petani, gabungan kelompok tani, pedagang, instasi terkait dan perguruan tinggi serta peluang dan tantangan pengembangan industri hilir kakao di Provinsi Papua Barat.

\section{KAKAO SEBAGAI KOMODITAS UNGGULAN STRATEGIS NASIONAL}

\section{Kondisi Usaha Perkebunan Kakao}

Luas areal pengembangan kakao di Indonesia dalam kurun waktu lima tahun terus mengalami peningkatan, yaitu seluas 1.491 Ha pada tahun 2009 dan meningkat seluas 1.768 ha pada tahun 2013 (Direktotar Jenderal Perkebunan 2015). Peningkatan luas areal pengembangan kakao ternyata tidak dikuti oleh produksi perkebunan rakyat dalam kurun waktu yang sama. Produksi kakao perkebunan rakyat dengan jumlah produksi 742 ribu ton di tahun 2009 meningkat menjadi 772 ribu ton di tahun 2010 atau peningkatan sekitar 4,04\% kemudian terjadi penurunan secara berfluktuasi dengan jumlah produksi 723 ribu ton di tahun 2013 (Direktotar Jenderal Perkebunan 2015). Penyebab utama penurunan produksi adalah karena menipisnya unsur hara tanah, serangan hama Penggerek Buah Kakao (PBK) dan penyakit Vascular Streak Dieback (VSD), menurunnya kualitas kebun juga masih belum optimalnya pengembangan produk hilir kakao (Maswadi 2011).

Perluasan areal perkebunan kakao yang sangat pesat umumnya dilakukan petani, sehingga perkebunan rakyat telah mendominasi perkebunan kakao Indonesia. Keberhasilan perluasan areal dan peningkatan produksi tersebut telah memberikan hasil nyata bagi peningkatan pangsa pasar kakao Indonesia di kancah kakao dunia. Indonesia berhasil menempatkan diri sebagai produsen 
kakao terbesar kedua dunia setelah Pantai Gading (Cote d'Ivore) sejak tahun 2002, walau pernah tergeser ke posisi ketiga oleh Ghana pada tahun 2003. Di antara negara produsen kakao terbesar, pertumbuhan produksi telah dicapai oleh Ghana (naik sebesar 269.000 ton), Indonesia (naik sebesar 99.000 ton), Kamerun (naik sebesar 81.000 ton), Nigeria (naik sebesar 67.000 ton), Ekuador (naik sebesar 41.000 ton) dan Brasil (naik sebesar naik 20.000 ton), sebaliknya, Malaysia mengalami penurunan produksi (turun 28.000 ton) (International Cocoa Organization, 2010). Perubahan produksi biji kakao dunia tahun 2000/2001-2009/2010 disajikan pada Gambar 1.

\section{Kondisi Ekspor Kakao Nasional}

Ekspor kakao Indonesia terus mengalami peningkatan dari tahun ke tahun. Pada tahun 2009, ekspor kakao berjumlah 535.236 ton dengan nilai sebesar US\$ 1.413.535 (Hasibuan et al. 2012). Hanya saja komoditas kakao Indonesia sebagian besar masih diekspor dalam bentuk komoditas primer yaitu biji kakao kering sehingga harganya relatif masih rendah. Sebanyak
439.305 ton dari 535.236 ton ekspor kakao Indonesia atau lebih dari $82 \%$ diekspor dalam bentuk biji, selebihnya diekspor dalam bentuk kakao buah, pasta, butter, tepung dan makanan yang mengandung coklat (Direktorat Jenderal Perkebunan 2010). Jumlah ekspor kakao Indonesia terus meningkat hingga trisemester pertama di tahun 2015 yang mencapai total sebesar US\$ 97.291.557 (Direktorat Jenderal Perkebunan 2015). Adapun beberapa negara tujuan utama ekspor kakao Indonesia adalah Korea, China, Singapura, Phlipina, Malaysia, Amerika Serikat, dan Jerman.

Harga kakao domestik mengikuti harga kakao internasional terutama harga di bursa New York karena sebagian besar ekspor kakao Indoensia ditujukan ke Amerika Serikat. Harga kakao dunia berfluaktif mulai dari US\$ 800/ton di tahun 2000 dan mencapai US\$ 3000-3500/ton di tahun 2010 (International Cocoa Organization 2010). Sedangkan harga biji kakao domestik di Makassar di tahun 2013 Rp 27.138/ kg (BPS 2015).

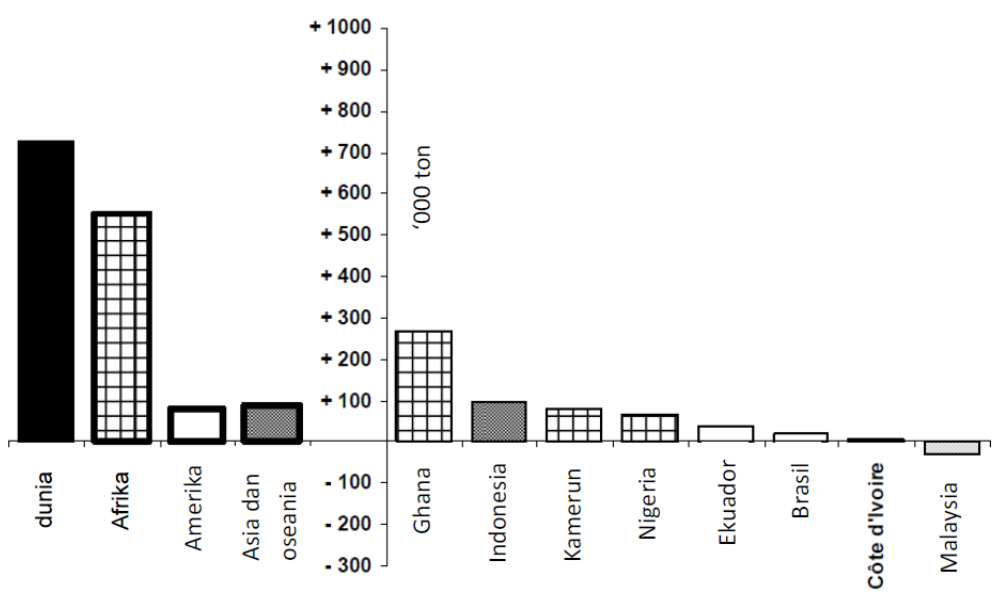

Gambar 1. Perubahan Produksi Biji Kakao Tahun 2000/2001-2009/2010 (ICCO 2010) 


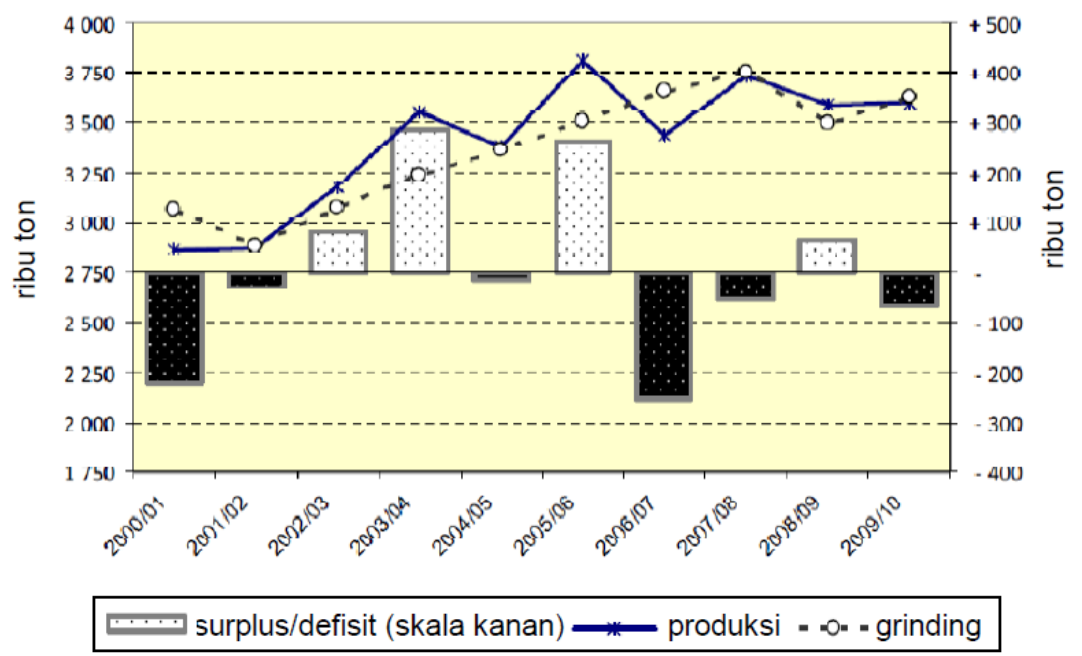

Gambar 2. Produksi Kakao Dunia untuk Biji Kakao, Grinding dan Surplus/Defisit (ICCO 2010)

\section{Prospek Pasar}

Prospek pasar kakao dunia juga telah dipaparkan dalam ICCO (2010). Produksi kakao dunia mengalami penurunan cukup tajam pada tahun 2000/01 dengan defisit stok kakao dunia sebesar 220 ribu ton, namun pada periode 2005/06 telah terjadi surplus stok kakao dunia sebesar 265 ribu ton. Hingga tahun 2009/10 kembali produksi kakao dunia mengalami penurunan sebesar 69 ribu ton setelah produksi kako dunia telah melampau surplus 67 ribu ton. Sebaliknya, pengolahan (grinding) biji kakao terus meningkat meningkat rata-rata sebesar 3,2\% per tahun selama periode 2000/01-2007/08. Grinding menunjukkan tren lebih konsisten daripada produksi, naik dari 3,1 juta ton lebih di tahun 2000/01 meningkat menjadi 3,5 juta ton lebih di tahun 2007/08. Produksi kakao dunia untuk biji kakao, grinding dan surplus/defisit disajikan pada Gambar 2.

Keseimbangan produksi dan konsumsi kakao dunia seperti yang dijelaskan diatas diperkirakan terus berlanjut, bahkan lebih cenderung mengalami defisit karena beberapa negara produsen utama menghadapi berbagai kendala dalam upaya meningkatkan produksinya untuk mengimbangi kenaikan konsumsi. Beberapa negara produsen kakao dunia menghadapi masalah seperti Pantai Gading mengurangi subsidi dan kestabilan politik dalam negeri, Ghana dan Kamerun menghadapi masalah subsidi dan insentif harga dari pemerintah sedangkan Malaysia menghadapi masalah ganasnya serangan hama PBK dan kebijakan untuk berkonsentrasi ke kelapa sawit.

Kondisi tersebut sangat menguntungkan Indonesia, karena keinginan masyarakat untuk mengembangkan perkebunan kakao beberapa tahun terakhir sangat besar dan sumber daya lahan masih tersedia. Provinsi-provinsi yang termasuk dalam wilayah pengembangan akibat GERNAS memiliki peluang untuk berkontribusi dalam produksi kakao nasional. Namun masih perlu memperhatikan beberapa hal terutama revitalisasi kebun, peremajaan dan perluasan areal disamping perbaikan mutu produksi dan pengembangan industri hilirnya.

\section{KONDISI PERKEBUNAN DAN PASCAPANEN KAKAO DI PROVINSI PAPUA BARAT}

\section{Keadaan Usaha Perkebunan Kakao}

Perkebunan kakao di Papua Barat diusahakan oleh perusahaan dan perkebuan rakyat dengan pola PIR, serta kebun individu masyarakat tani. Perkebunan kakao hampir terdapat diseluruh kabupaten dengan luas areal terluas di Kabupaten Manokwari (1.485 Ha) dan Kabupaten Manokwari Selatan (1.209 Ha) (Tabel 1). Sentra produksi kakao di Kabupaten Manokwari Selatan berada di Distrik Oransbari. Bibit kakao di distrik tersebut berasal dari bibit yang disediakan oleh Dinas Perkebunan pada tahun 1980- 
1990. Selain itu, pada tahun 2008 petani di Kampung Sidomulyo juga mendapatkan bantuan bibit yang berasal dari Jember.

Tanaman kakao yang dikembangkan di Distrik Oransbari terdiri dari dua kultivar yaitu kultivar Lokal dan kultivar Jember. Kultivar Lokal memiliki ukuran buah lebih kecil dibandingkan dengan kultivar Jember yang ditandai dengan lebih rendahnya bobot buah, panjang buah maupun ukuran diameter buah (Tabel 2). Jumlah biji/buah dari kultivar Lokal juga lebih rendah dibandingkan kultivar Jember masing-masing berjumlah 35 dan 43 biji/buah, begitu juga bobot biji/buah kultivar Lokal lebih rendah dibandingkan kultivar Jember masing-masing berbobot 148 dan 165 $\mathrm{g} /$ buah (Tabel 2). Jumlah biji dalam $100 \mathrm{~g}$ biji kakao kering yang telah difermentasi untuk kultivar Lokal dan kultivar Jember masingmasing berjumlah 96 biji dan 86 biji. Jumlah biji/100g sebesar 95,5 digolongkan dalam mutu B yaitu golongan biji dengan ukuran medium dengan jumlah biji 95-110, sedangkan jumlah biji/100g sebesar 85,5 digolongkan mutu A yaitu golongan biji dengan ukuran besar dengan jumlah biji antara 85-100 (Mulato dkk. 2005).

Pengembangan agribisnis kakao di Provinsi Papua Barat difokuskan terutama di sentra-sentra perkebunan lebih diprioritaskan pada upaya rehabilitasi dan peremajaan untuk meningkatkan produktivitas kebun kakao, disamping terus melakukan perluasan. Peningkatan pengetahuan dan keterampilan petani juga merupakan salah satu kunci keberhasilan dan pengembangan perkebunan kakao di suatu wilayah. Pada saat ini belum semua petani kakao Provinsi Papua Barat memiliki pengetahuan mengelola perkebunan kakao secara baik. Oleh karena itu diperlukan dukungan kebijakan untuk membenahi atau merevitalisasi lembaga dan program penyuluhan petani kakao. Perlu adanya kelembagann ekonomi petani yang merupakan wadah bagi petani kakao untuk tumbuh dan berkembang bersama-sama dan mengatasi berbagai kendala dan permasalahan secara bersama-sama.

Tabel 1. Luas Areal, Produksi dan Petani Kakao Provinsi Papua Barat

\begin{tabular}{lrrrr}
\hline \multicolumn{1}{c}{ Kabupaten } & $\begin{array}{r}\text { Luas area TM } \\
(\mathrm{Ha})\end{array}$ & $\begin{array}{c}\text { Produksi } \\
\text { (ton) }\end{array}$ & $\begin{array}{c}\text { Produktivitas } \\
(\mathrm{Kg} / \mathrm{Ha})\end{array}$ & $\begin{array}{c}\text { Jumlah Petani } \\
(\mathrm{KK})\end{array}$ \\
\hline Manokwari & 1.485 & 1.039 & 700 & 2.393 \\
Kab. Sorong & 897 & 121 & 135 & 1.015 \\
Sorong Selatan & 501 & 301 & 601 & 1.686 \\
Raja Ampat & 237 & 31 & 350 & 375 \\
Teluk Bintuni & 36 & 9 & 246 & 53 \\
Teluk Wondama & 268 & 188 & 701 & 350 \\
Fak-Fak & 42 & 14 & 333 & 157 \\
Kaimana & 79 & 68 & 861 & 226 \\
Kota Sorong & 12 & 10 & 833 & 55 \\
Tembrauw & 738 & 415 & 562 & 871 \\
Mabrat & 5 & 2 & 400 & 65 \\
Manokwari Selatan & 1.209 & 907 & 750 & 180 \\
Pegunungan Arfak & - & - & - & - \\
\hline Jumlah & 5.509 & 3.104 & 539 & 7.426 \\
\hline
\end{tabular}

Keterangan TM : Tanaman Menghasilkan

Sumber : Dinas Perkebunan Papua Barat (2015)

Tabel 2. Rata-rata bobot buah, diameter buah, bobot pod, jumlah biji/buah dan bobot biji/buah kultivar Lokal dan Jember

\begin{tabular}{|c|c|c|c|c|c|c|c|c|}
\hline \multirow[t]{2}{*}{ Kultivar } & \multirow{2}{*}{$\begin{array}{c}\text { Bobot } \\
\text { buah } \\
\text { (g) }\end{array}$} & \multirow{2}{*}{$\begin{array}{c}\text { Panjang } \\
\text { buah } \\
(\mathrm{cm})\end{array}$} & \multicolumn{3}{|c|}{ Diameter buah $(\mathrm{cm})$} & \multirow{2}{*}{$\begin{array}{l}\text { Bobot } \\
\text { pot }(g)\end{array}$} & \multirow{2}{*}{$\begin{array}{c}\text { Jumlah } \\
\text { biji/buah }\end{array}$} & \multirow{2}{*}{$\begin{array}{c}\text { Bobot } \\
\text { biji/buah (g) }\end{array}$} \\
\hline & & & Pangkal & Tengah & $\begin{array}{l}\text { ujun } \\
\mathrm{g}\end{array}$ & & & \\
\hline Lokal & 426 & 15,67 & 5,33 & 10,5 & 5,7 & 321 & 35 & 148 \\
\hline Jember & 634 & 18,67 & 8,75 & 12,4 & 9,6 & 486 & 43 & 165 \\
\hline
\end{tabular}

Sumber : Murtiningrum et al. (2013) 


\section{Penanganan Pascapanen Kakao}

Petani kakao (100\%) di beberapa daerah sentra produksi kakao Papua Barat (Pantura, Oransbari, Warmare, SP 5 Prafi, SP 10 Prafi dan SP 11 Prafi) belum melakukan proses fermentasi pada proses pascapanen biji kakao. Hal ini terjadi karena kurangnya pemahaman dari para petani tentang tujuan utama dilakukannya proses fermentasi biji kakao. Pada umumnya petani hanya meletakkan biji kakao basah di dalam karung plastik yang ditindih dengan alat pemberat (batu ataupun kayu balok) dan membiarkannya 1-2 malam hingga kandungan airnya berkurang. Proses yang terjadi selama penyimpanan di dalam karung adalah "pseudo-fermentasi" yang sama sekali tidak mempunyai andil dalam perbaikan mutu.

Pengeringan biji kakao juga dilakukan dengan cara sederhana dengan menggunakan panas surya. Teknik penjemuran yang dilakukan oleh sebagian besar petani adalah dengan menghamparkan biji kakao basah diatas terpal plastik yang diletakkan di halaman rumah. Selain itu para petani lokal (masyarakat asli Papua) lebih sering menjemur biji kakao pada sisi jalan raya. Hanya sebagian kecil petani yang menggunakan para-para atau anyaman bambu sebagai tempat penjemuran biji kakao basah. Petani hanya membutuhkan panas surya untuk mengeringkan biji kakao yang dijemur, sehingga proses penjemuran sangat bergantung pada cuaca (panas surya). Petani harus selalu menjaga biji kakao bila cuaca kurang cerah. Bila cuaca hujan biji kakao akan sangat mudah terserang jamur dan mikroorganisme. Selain itu kebersihan biji kakao tidak terjamin karena mudah terkena debu maupun kotoran ternak
Akibatnya mutu kakao kering yang dihasilkan sangat rendah. Penjualan hasil panen belum sepenuhnya mengikuti standar nasional Indonesia (SNI), sehingga semua jenis panen yang kurang bermutupun tetap diterima pasar dengan harga yang berbeda. Kenyataan di lapangan pada beberapa daerah sentra produksi kakao di Provinsi Papua Barat, mengindikasikan bahwa penentu bisnis kakao adalah pedagang perantara (pengumpul) yang orientasinya hanya pada keuntungan semata. Pedagang pengumpul tidak memperdulikan pada jenis kakao yang difermentasi maupun yang tidak difermentasi. Usaha masyarakat untuk melakukan fermentasi ternyata diganggu oleh pedagang, yang hanya mau membeli biji kakao kering apa adanya, sebelum fermentasi sempurna. Hal diatas sangat disayangkan karena kualitas kakao yang dihasilkan di Manokwari apabila difermentasi dengan sempurna memiliki kualitas lebih baik dari pada kualitas kakao Sulawesi Selatan sehingga dgunakan untuk pengoplosan untuk meningkatkan kualitas kakao Sulawesi Selatan.

Permasalahan yang diuraikan diatas, melatarbelakangi kegiatan $\mathrm{I}_{b}$ IKK (Ipteks Bagi Inovasi Kreativitas Kampus) Kakao UNIPA (Universitas Papua) dengan kegiatan utama mendirikan unit pengolahan pascapanen kakao. Bangunan unit pengolahan pascapanen kakao dengan luas $28 \mathrm{~m}^{2}$ yang terdiri atas peralatan proses utama yaitu unit fermentasi kakao (kapasitas produksi 80-90 kg/batch) dan rumah pengering (kapasitas $90 \mathrm{~kg} / \mathrm{batch}$ ) (Gambar 3). Kegiatan $\mathrm{I}_{\mathrm{b}} \mathrm{IKK}$ kakao ini dapat menjadi contoh bagi masyarakat petani kakao di Manokwari tentang penanganan pascapanen kakao hingga menghasilkan biji kakao kering fermentasi sesuai standar.
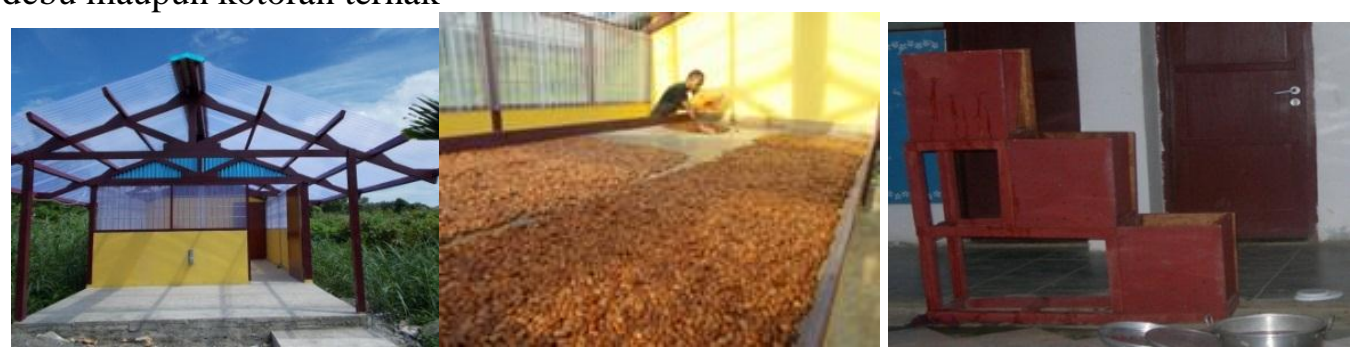

Gambar 3. Unit Pengolahan Pascapanen $\mathrm{I}_{b} \mathrm{IKK}$ Kakao UNIPA (foto Murtiningrum) 


\section{ARAH PENGEMBANGAN KAKAO DI PROVINSI PAPUA BARAT}

\section{Penguatan Kelembagaan}

Permasalahan utama perkebunan kakao di Provinsi Papua Barat sebagian besar masih bertumpu pada petani yaitu rendahnya produktivitas dan mutu produk kakao serta permasalahan harga yang diterima petani tidak berbeda antara biji kakao fermentasi dan non-fermentasi. Permasalahan-permasalahan tersebut seharusnya tidak dihadapi sendiri oleh petani tetapi perlu dukungan kerjasama dari pihak-pihak atau lembaga lain dalam lingkup perkebunan kakao.

Petani berperan sebagai pemilik perkebunan kakao menghasilkan buah kakao dan mendapat pembayaran langsung (tunai) pada saat menjual hasil panennya berupa biji kakao kering (non fermentasi). Kegiatan usaha tani hingga pascapanen yang dilakukan petani memerlukan waktu panjang dan dilakukan sendiri oleh keluarga inti petani yang terdiri atas ayah, ibu dan terkadang pada saat panen dibantu oleh saudara dekat dari keluarga inti. Keterbatasan tenaga dan waktu mengakibatkan petani keberatan melakukan proses pengolahan biji kakao fermentasi yang memerlukan tambahan waktu 4-5 hari, apalagi harga yang diterima dari penjualan biji fermentasi dan non fermentasi tidak berbeda jauh.

Kegiatan usaha tani kakao oleh petani meliputi pemangkasan, pembuangan tunas air, pemupukan, pengendalian gulma, pengendalian hama dan penyakit dan pemanenan. Untuk kegiatan pascapanen, petani memerlukan waktu 1-2 hari untuk membelah buah dan mengeluarkan bijinya. Pemanenan oleh sebagian besar petani masih dilakukan dengan cara manual yaitu menggunakan parang untuk membelah buah kakao. Selanjutnya biji kakao basah diperam dalam karung selama 1-2 malam dan dilanjutkan dengan pengeringan biji pada lantai-lantai jemur di pekarangan rumah. Tidak jarang sebelum biji kakao mencapai kadar air yang dipersyaratkan, petani telah menjual hasil panen pada pedagang-pedagang pengumpul. Keputusan petani ini mengakibatkan rendahnya pendapatan yang diterima oleh petani.
Oleh karena itu, dengan pertimbangan efisiensi dan skala usaha seharusnya proses pascapanen biji kakao dilakukan di tingkat kelompok tani. Kelompok tani membentuk sub-sub kelompok yang terdiri atas penanganan pascapanen, sarana prasarana, pengawasan mutu dan pembelian dan pemasaran. Kegiatan terintegrasi yang dilengkapi sarana dan prasarana untuk melakukan kegiatan penanganan pascapenen, sampai dengan pemasaran biji kakao yang dilakukan dalam satu atap manajemen. Kelompok tani ini harus menjalin kerjasama dengan petani, sehingga petani merupakan asset yang sangat berharga karena untuk menjamin ketersediaan bahan baku (biji kakao basah).

Perlengkapan yang harus dimiliki pada kelompok tani seperti peralatan mesin pemecah buah, unit fermentasi, ruang pengering, mesin sortasi, ruang pengering dan peralatan lainnya berada di kelompok petani. Kelompok tani menghasilkan biji kakao kering fermentasi yang sesuai standar mutu untuk kebutuhan industri sesuai dengan persyaratan mutu SNI. Sebenarnya proses fermentasi dapat meningkatkan harga jual biji kakao dan dapat berdampak pada peningkatan pendapatan petani secara keseluruhan. Secara umum harga kakao biji non fermentasi di tingkat petani beberapa tahun terakhir berkisar antara Rp 20.000-Rp 25.000/kg/biji kering, sedangkan untuk kakao biji kakao fermentasi berkisar antara Rp 30.000-Rp 35.000/kg/biji kering.

Kelompok-kelompok tani yang berada di satu desa harus membentuk gabungan kelompok tani (gapoktan) yang dapat ditransformasikan menjadi koperasi petani (Listyati et al. 2014). Gapoktan/koperasi tersebut berperan sebagai : 1) penyedia sarana produksi usahatani kakao bagi petani/kelompok tani (pupuk, pestisida, benih), 2) koperasi simpan pinjam, 3) penyalur biji kakao dari tingkat kelompok petani, 4) penyedia dana talangan untuk produksi bij kakao yang dihasilkan oleh petani/kelompok tani (Listyati et al. 2014).

Tidak semua kelompok tani memiliki sarana transportasi untuk menjual hasil panen langsung ke pedagang besar. Peran pedagang pengumpul untuk mendatangi kelompok tani yang telah siap menjual biji 
kakao fermentasi dengan kualitas sesuai dengan SNI. Selanjutnya pedagang-pedagang pengumpul dapat menjual pada pedagang besar yang dapat memberikan harga yang berbeda antara biji kakao fermentasi dan non fermetasi. Bagi pedagang pengumpul dan pedagang besar adanya peningkatan produktivitas dan mutu kakao akan memberikan manfaat tersendiri yaitu adanya kemudahan untuk mendapatkan biji kakao dan jaminan tersedianya pasokan bahan baku biji kakao dengan kualitas yang sesuai dengan yang dikehendaki perusahaan Instansi terkait juga dapat melakukan pembinaan kepada petani, kelompok tani maupun gapoktan dengan melibatkan tenaga profesional dari luar, baik dari perguruan tinggi maupun dari lembaga profesi lainnya. Efisiensi dan efektifitas program-program bantuan ke petani yang dilaksanakan oleh Satuan Kerja Perangkat Daerah (SKPD), ketepatan sasaran program bantuan usaha tani, kelompok target pembinaan dapat lebih terarah, dan kemudahan dalam pengawasan pelaksanaan program-program pengembangan usaha tani. Penerapan IPTEKS hasil penelitian perguruan tinggi harus dapat diadopsi oleh petani sebagai pelaku utama dalam agroindustri kakao. Sebagai contoh, unit pengolahan pascapanen IBIKK Kakao UNIPA (Gambar 3) dapat diadopsi untuk meningkatkan mutu biji kakao fermentasi. Petani dibina secara baik mulai dari persiapan lahan, penyediaan bibit, pemeliharaan pemanenanan hingga penanganan pascapanen.

Berdasarkan urauan diatas, maka kelembagaan kakao di Provinsi Papua Barat sebenarnya sudah ada namun belum berjalan secara efisien dan efektif dan belum dirasakan keberadaannya oleh semua pelaku bisnis kakao. Kelembagaan informal yang ada mengakibatkan pedagang memiliki posisi tawar yang lebih kuat dibandingkan petani. Pembaruan melalui penguatan kelembagaan kakao perlu dilakukan agar dapat berjalan sesuai perannya sehingga pada akhirnya mampu mencapai tujuan bersama. Kelembagaan kakao pada prinsinya melibatkan beberapa pihak mencakup petani/kelompok tani/gapoktan/asosiasi petani, industri pengolahan kakao, lembaga pembiayaan, lembaga penyuluhan, perguruan tinggi/litbang dan instansi terkait (kebijakan) (Listyati et al. 2014).

Kelembagaan kakao merupakan alternatif pemecahan yang dapat dilakukan agar tercipta pengorganisasian hubungan fungsional dengan cara penyatuan aktivitas dalam ikatan usaha yang saling menunjang dan saling tergantung dalam suatu ikatan usaha yang memiliki tujuan yang sama. Beberapa pakar memandang bahwa kelembagaan sebagai hubungan yang harmonis antar individu atau kelompok dalam rangka pengembangan ekonomi lokal. Kelembagaan lebih dianggap sebagai hubungan sosial antar individu atau antar kelompok dimana hubungan akan terjalin secara harmonis dikarenakan adanya kesepakatan mencapai tujuan bersama maka diperlukan organisasi atau lembaga yang pada dasarnya merupakan wadah untuk mewujujdkan berbagai tujuan bersama secara terorganisir dan berkesinambungan (Sholahuddin 2001).

Penguatan kelembagaan kakao di Provinsi Papua Barat dapat diatasi dengan pengorganisasian antara petani, kelompok petani, gapoktan, pedagang pengumpul, pedagang besar, instansi terkait dan perguruan tinggi. Penguatan kelembagaan bisa berjalan efektif dan efisien jika mendapat dukungan dari seluruh pihak yang terkait dengan mengetahui peran, fungsi dan aktivitas lembaga atau pihak yang terkait dalam kelembagaan tersebut. Rekomendasi model kelembagaan kakao di Provinsi Papua Barat disajikan pada Gambar 4.

\section{Peluang dan Tantangan Pengembangan Industri Hilir}

Daya saing Indonesia terhadap Malaysia di pasar Cina hanya unggul untuk biji kakao, sementara itu untuk produk olahan kakao (kakao bubuk, lemak dan pasta kakao dan coklat konsumsi malaysia lebih ungul dibandingkan Indonesia (Lubis \& Nuryanti 2011). Dikatakan lebih lanjut bahwa pasar produk kakao impor di Cina mulai bergeser dari biji kakao menjadi produk olahan. Perubahan ini merugikan Indonesia karena masih mengandalkan ekspor untuk produk bahan baku yaitu biji kakao yang belum terfermentasi. Kondisi ini jika tidak segera diperbaiki akan menyebabkan Indonesia tidak 
lagi melakukan ekspor langsung ke Cina, namun harus melalui negara ketiga dalam hal ini Malaysia. Oleh karena itu produk biji kakao harus dialihkan ke produk bernilai tambah seperti biji kakao terfermentasi, dan selanjutnya mengkhususkan mengekspor produk setengah jadi terutama lemak dan pasta kakao untuk mempertahankan pangsa produk kakao Indonesia di pasar Cina.

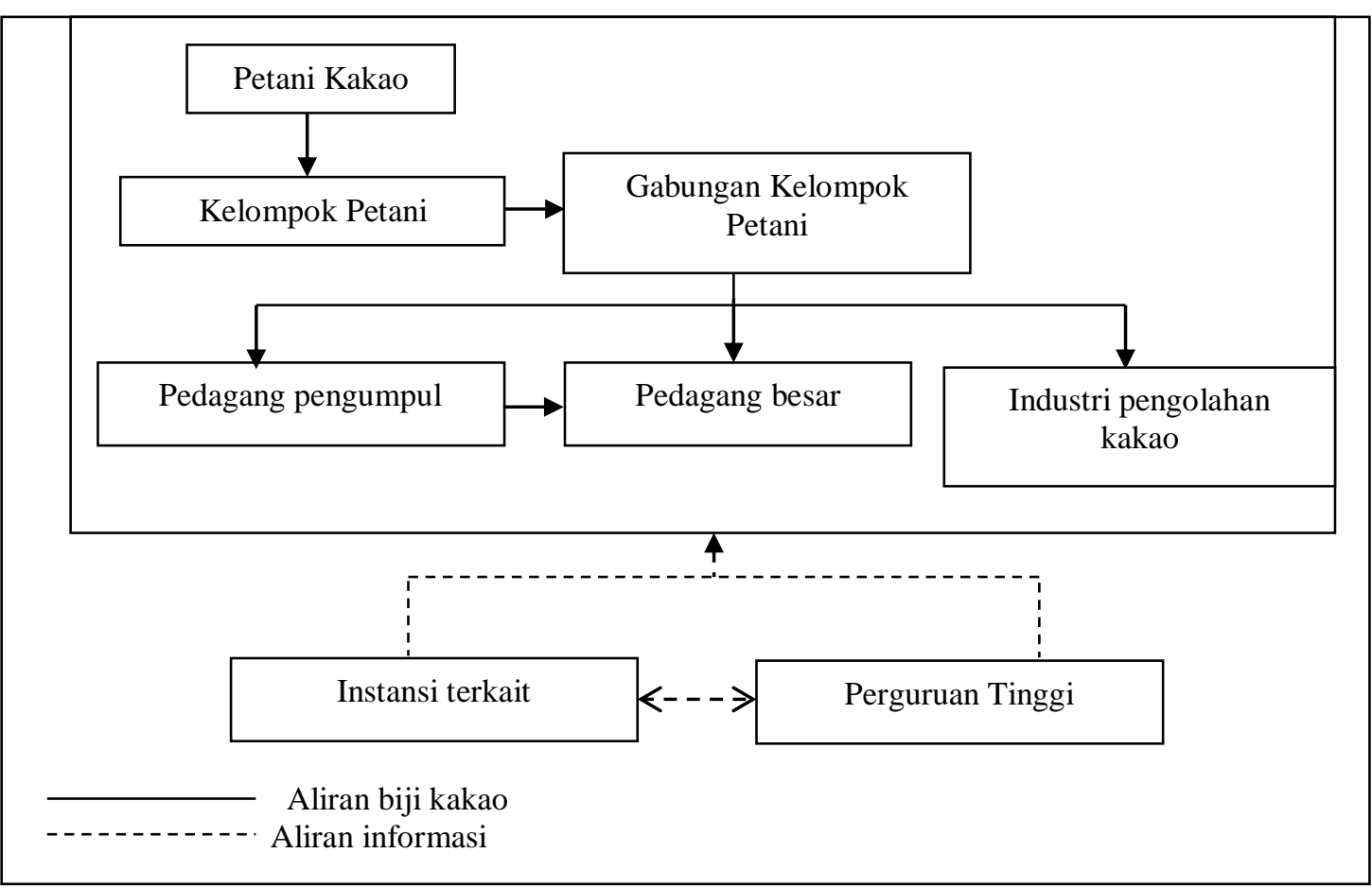

Gambar 4. Konsep Kelembagaan Kakao di Provinsi Papua Barat (Listyati et al. 2014, dimodifikasi)

Industri hilir atau pengolahan produk sekunder kakao menggunakan biji kakao sebagai bahan baku utama dalam proses produksinya. Biji kakao pada umumnya digunakan oleh industri pengolahan kakao untuk dijadikan produk olahan setengah jadi atau makanan cokelat jadi yang kemudian dikonsumsi langsung oleh konsumen atau sebagai bahan baku bagi beberapa industri makanan dan minuman. Biji kako yang baik untuk diolah adalah biji kakao yang telah melewati tahap fermentasi, karena pada tahap fermentasi bertujuan untuk membebaskan biji kako dari pulp dan untuk memperbaiki dan membentuk citarasa kakao yang enak dan menyenangkan serta mengurangi rasa sepat dan pahit pada biji (Emmanuel et al. 2012; Afoakwa et al. 2012).
Peluang pengembangan industri hilir kakao masih sangat besar jika dilihat dari berlimpahnya bahan baku yang tersedia serta peluang untuk memperoleh nilai tambah dan penyerapan tenaga kerja yang sangat besar. Perusahaan-perusahaan pengolahan kakao di Indonesia umumnya berlokasi di pulau Jawa dan beberapa berada di Makasar, Medan dan Kendari. Jika ditinjau dari letak industri pengolahan kakao yang umumnya berada di pulau Jawa dengan letak sentra perkebunan kakao yang berada di di wilayah Indonesia Timur (pulau Sulawesi dan Papua), tentunya perbedaan jarak ini akan menimbulkan biaya transportasi yang besar dalam pengriman bahan baku. Oleh karena itu, pengembangan industri pengolahan kakao di daerah sentra perkebunan kakao akan memperkuat keterkaitan semua tingkatan rantai nilai dari 
industri sebagai upaya untuk membangun jaringan industri pengolahan kakao.

Pengembangan industri pengolahan kakao di Provinsi Papua Barat dapat ditingkatkan apabila dikembangkan proses pengolahan kakao secara sederhana menggunakan teknologi tepat guna, sehingga para petani kakao dapat menghasilkan produk hilir kakao yang memiliki nilai tawar ekonomi lebih tinggi. Langkah awal yang perlu dilakukan adalah menyiapkan sarana dan teknologi pengolahan biji kakao menghasilkan produk sekunder yang memeiliki nilai tawar yang lebih tinggi. Kemudian dilakukan pelatihan terhadap para petani dan melakukan praktek pengolahan kakao yang memanfaatkan teknolgi alat pengolahan menghasilkan bubuk kakao, lemak kakao dan kulit biji kakao.

Penataan usaha tani yang baik melalui penguatan kelembagaan, diharapkan pasokan bahan baku untuk industri hilir makin lancar dan berkualitas sehingga pertumbuhan agroindustri hilir secara keseluruhan meningkat pula. Pengembangan industri hilir kakao di Provinsi Papua Barat memerlukan kerjasama yang sinergis antara petani, kelompok tani, pedagang, perguruan tinggi dan instansi terkait. Kerjasama tersebut dapat menciptakan kekuatan usaha baru, memperluas jangkauan pasar, menjadikan usaha tangguh, dan penjaminan mutu produk.

\section{KESIMPULAN}

Pengembangan agroindustri kakao di Provinsi Papua Barat memerlukan pembaruan dengan penguatan kelembagaan kakao antara petani, kelompok petani, gapoktan, pedagang pengumpul, pedagang besar, instansi terkait dan perguruan tinggi. Kerjasama tersebut dapat menciptakan kekuatan usaha baru, memperluas jangkauan pasar, dan penjaminan mutu produk. Nilai tambah yang dihasilkan komoditas kakao di Provinsi Papua Barat belum optimal karena lemahnya strategi pengembangan industri dan kemampuan membangun industri hilir. Nilai tambah bagi para petani kakao dapat ditingkatkan apabila dikembangkan proses pengolahan kakao secara sederhana menggunakan teknologi tepat guna, sehingga para petani kakao dapat menghasilkan prroduk hilir kakao yang memiliki nilai ekonomi lebih tinggi.

\section{UCAPAN TERIMA KASIH}

Ucapan terima kasih kami tujukan kepada Direktorat Penelitian dan Pengabdian Kepada Masyarakat Direktorat Jenderal Pendidikan Tinggi Kementerian Pendidikan dan Kebudayaan melalui kegiatan "Inovasi Bagi Kereativitas Kampus" tahun 2012-2014. Ucapan terimakasih juga disampaikan kepada saudara Decky Worabai atas bantuan pengumpulan data dalam tulisan ini.

\section{DAFTAR PUSTAKA}

Afoakwa EO, Quao J, Takrama FS, Budu AS and Saalia FK. 2012. Changes in total polyphenols, o-diphenols and anthocyanin concentrations during fermentation of pulp pre-conditioned cocoa (Theobroma cacao) beans. International Food Research Journal 19 (3) : 1071-1077.

BPS. 2015. http://www.bps.go.id/ [diunduh 6 Juli 2015].

Direktorat Jenderal Perkebunan. 2015. http://ditjenbun.pertanian.go.id/ [diunduh 6 Juli 2015].

Direktorat Jenderal Perkebunan. 2010. Statistik Perkebunan 2009-2011:Kakao Direktorat Jenderal Perkebunan, Kementerian Pertanian, Jakarta.

Dinas Perkebunan Papua Barat. 2015. Fakta Integritas_Data Bun PB 2014. Manokwari

Emmanuel OA, Jennifer Q, Agnes SB, Jemmy ST and Firibu KS. 2012. Influence of pulp-preconditioning and fermentation on fermentative quality and appearance of Ghanaian cocoa (Theobroma cacao) beans. International Food Research Journal 19 (1) : 127-133.

Hasibuan AM, Nurmalina R dan Wahyudi A. 2012. Analisis kebijakan pengembangan industri hilir kakao (suatu pendekatan sistem dinamis). Informatika pertanian 21(2) : 59-70.

International Cocoa Organization. 2010. Quarterly Buletin of Cocoa Statistics. London.

Listyati D, Wahyudi A dan Hasibuan AM. 2014. Penguatan kelembagaan untuk peningkatan posisi tawar petani dalam 
sistem pemasaran kakao. J. TIDP 1 (1) $: 15-28$.

Lubis AD dan Nuryanti S. 2011. Analisis dampak ACFTA dan kebijakan perdagangan kakao di pasar domestik dan china. Analisis Kebijakan Pertanian 9 (2) : 143-156.

Maswadi. 2011. Agribisnis kakao dan produk olahannya berkaitan dengan kabijakatan tarif pajak di Indonesia. $J$. Perkebunan \& Lahan Trilopika 1 (2) : 23-30.

Mulato S dan Widyatomo S. 2003. Standarisasi Mutu Biji Kakao. Pusat Penelitian Kopi dan Kakao Indonesia. Jember
Murtiningrum, Jading A, Santoso B dan Kurniawan A. 2013. Laporan Kegiatan Inovasi Bagi Kreativitas Kampus (IbIKK) Kakao Universitas Negeri Papua Manokwari. Universitas Negeri Papua. Manokwari

Neilson J. 2008. Program Gerakan Nasional Percepatan Revitalisasi Kakao Nasional (GERNAS). ACIAR : 1:42.

Sholahuddin S. 2001. Analisis Kelembagaan Pengembangan Agroindustri (Studi kasus Kabupaten Tebo, Jambi). Jurnal Ilmiah Kesatuan 3(1):23-27. 